\title{
Nanotechnology and its potential applications in meat industry
}

\author{
Baltić Ž. Milan ${ }^{1}$, Bošković Marija ${ }^{1}$, Ivanović Jelena ${ }^{1}$, Dokmanović Marija ${ }^{1}$, Janjić Jelena ${ }^{1}$, Lončina ${ }^{1}$ Jasna, \\ Baltić2 Tatjana
}

$S$ u $\mathrm{m} m$ a $r y$ : The food industry is making great efforts to improve hygiene, extend the shelf life of products, prevent food-borne illnesses and contamination by chemical and also physical agents, and to improve their detection and control if contamination already has occurred. As a result, there is a constant search for new technologies which can help in achieving these goals. Nanotechnology is one of the major innovations which have already been applied in many different areas. Results of previous studies show that the use of nanotechnology provides a number of opportunities to improve processes of production, packaging, distribution and storage of the food, and therefore of the meat, as one of the most valuable source of nutritional components.

Key words: nanotechnology, nano-packaging, meat, issue and benefits.

\section{Introduction}

Nanotechnology is relatively novel technology which may be the beginning of the second technical revolution (Ozimek et al., 2010). It is based on the characterization, fabrication and manipulation of structures or materials smaller than $100 \mathrm{~nm}$ (approximately 1-100 nm in length), (Azaredo, 2009; Ozimek et al., 2010; Duncan, 2011; Cushen et al., 2012; Coles and Frewer, 2013). Nanomaterials have at least one dimension, but depending on the form, they may have two or three dimensions (Ozimek et al., 2010). There are different forms of nonomaterial: nanoparticles (discrete entity that has three dimensions), nanotubes (cylindrical lattice arrangement of material), fullerenes (spherical molecular arrangement), nanofibres (a length to diameter ratio of at least 3:1, and are in the nano range), nanowhiskers (fine fibres in the nano range, and dimension of 5-20 nm in cross-section with lengths of several $\mu \mathrm{m}$ ) and nanosheets (material where only one dimension is in the nano range), (Ozimek et al., 2010; Cushen et al., 2012). Nanomaterials can be made from inorganic or organic materials, but in both cases they have different properties than larger particles of the same type. With the decrease in size, mechanical strength, electrical and thermal conductivity, chemical reactivity, transparency and magnetism are changing (Ozimek et al., 2010; Cushen et al., 2012). At the moment, there are two categories of nanomaterials manufacture: a "top-down" approach and the "bottom-up" approach. "Top down" manufacturing of nonomaterial involves breaking down larger particles of matter to particles of only nanometres in dimension, by using milling, nanolithography, or precision engineering. "Bottom up" manufacturing is the alternative production method of nanomaterials which includes crystallization, layer-by-layer deposition, solvent extraction/evaporation, self-assembly, microbial synthesis and biomass reactions (Azeredo, 2009; Cushen et al., 2012).

Since 1959, when Richard Feynman introduced the concept of nanotechnology at a meeting of the American Physical Society, it has developed rapidly, and nowadays it finds its application in many different areas such as electronics, human and veterinary medicine, textiles, defence, agriculture, cosmetics, etc. (Azeredo, 2009; Ozimek et al., 2010). The food sector, which is worth over 4 trillion US\$ per year, globally presents the target for new

Acknowledgments: This paper was supported by the Ministry of Education, Science and Technological Development, Republic of Serbia, Project TR 31034.

1 University of Belgrade, Faculty of Veterinary Medicine, Bulevar Oslobođenja 18, 11000 Belgrade, Republic of Serbia;

2Institute of Meat Hygiene and Technology, Kaćanskog 13, 11000 Belgrade, Republic of Serbia.

Corresponding author: Baltić Ž. Milan, baltic@vet.bg.ac.rs 
developments such as nanotechnology, which has a lot to offer on this field (Murray, 2007; Chaudhry and Castle, 2011). Some large food companies such as Kraft, Nestlé and Unilever experiment with nanotechnologies in order to make better, tastier, safer and more acceptable products for consumers $(\mathrm{Oz}$ imek et al., 2010). Nanotechnology offers possibility of reducing preservatives and other undesirable or potentially harmful substances in food products, affects development of new or improved tastes, textures and bioavailability of nutrients and supplements, and also may extend shelf-life and keep products safe from microbial pathogens. In spite of different ways of application of nanotechnology in food products, main focus, especially in regard to meat and meat products, are food packaging, such as "active" and "intelligent" packaging (Chaudhry and Castle, 2011).

\section{Potential applications of nanotechnology in meat and meat products}

Applications of nanomaterial's currently used for meat, and food generally, include the use of nanoparticles and nanomaterials as food ingredients/additives which are placed directly into food, or as a part of food packaging (Lee, 2010; Chaudhry and Castle, 2011; Duncan, 2011; Cushen et al., 2012; Azeredo, 2013; Rhim et al., 2013; Coles and Frewer, 2013).

Use of nano-encapsulated food additives and supplements represents a great advantage compared to conventional use of the same substances in food. Microencapsulating process can improve dispersing ability of fat-soluble additives in food products, enhance taste, and reduce the use of fat, salt, sugar and preservatives (Chaudhry and Castle, 2011). Reducing the salt level is especially important and presents a great challenge for meat industry because in spite of advantages, use of salt has shortcomings since it is linked to hypertension and consequently increased risk of cardiovascular disease (Desmond, 2006; Sofos 2008; Weiss et al., 2010; Bošković et. al, 2013).

Available nano-encapsulated additives include vitamins, antioxidants, colours, flavours, and preservatives. For nutrients and supplements such as omega- 3 fatty acids, vitamins $\mathrm{A}, \mathrm{E}$ and $\mathrm{D}_{2}$, isoflavones, $B$-carotene, nano-size carriers based on nano-encapsulated substances in liposomes, micelles or protein have been developed (Chaudhry and Castle, 2011; Cushen et al., 2012). One of the functions of nano-carrier systems is to protect nutrients and supplements from degradation during processing. For example, carriers enable nutritive substances to be resistant to proteases and other denaturing compounds, improve their stability to $\mathrm{pH}$ value and temperature changes, increase their ability to be transferred across intestinal membranes into the blood and controlled release, and better dispersion in aqueous systems for water-insoluble food ingredients and additives (Cushen et al., 2012). Nanotechnology can be utilized to improve the stability of such micronutrients not only during processing but storage and distribution, as well (Chen et al., 2006; Cushen et al., 2012).

Nanotechnology can improve the texture of foods, but this applies mainly to dairy products (Coles and Frewer, 2013). It may also mask the unpleasant or strong, and for consumers unacceptable taste and odour of some substances, such as fish oil, which is at the moment in this form commercially used only as microencapsulated fish oil added to bread, but there are implications that it can be used in other products (Chaudhry et al., 2008; Cushen et al., 2012). Studies conducted on essential oils, which may be used in meat because of their antibacterial properties in order to prevent food-borne diseases and to extend shelf-life, have shown that, depending on concentration, after application in meat, some essential oils may alter the qualitative properties of the product. A way to minimize negative organoleptic effects of essential oils added to the matrix of a meat is to encapsulate essential oils into nano-emulsions (Donsi et al., 2011; Hyldgaard et al., 2012; Bošković et. al, 2013).

However, the possibility should be considered that functionalities of nanomaterials applied directly into food could be affected by composition of a food (Cushen et al., 2012), such as proteins, fat or carbohydrates, and this needs to be investigated in order to improve product functionality without compromising food quality or safety.

\section{Nano-packaging}

Migration and permeability are two major issues associated with food packaging production. Polymer nanocomposites (PNCs) are the latest materials aimed at solving these problems and improvement of many other characteristics, such as gas and water vapour barrier properties, mechanical strength, thermal stability and chemical stability, recyclability, biodegradability, dimensional stability, heat resistance and optical clarity. This packaging supports the preservation of fresh foods, extending their shelf life and reducing the packaging waste associated with processed foods at the same time (Sorrentino et al., 2007; Lee, 2010; Duncan, 
2011). PNCs are created by dispersing an inert, nanoscale filler made from different materials (nanoplatelets, silica, carbon nanotubes, graphene, starch nanocrystals, cellulose-based nanofibers, chitin or chitosan nanoparticles, etc.) throughout a polymeric matrix (Duncan, 2011). Depending on their purpose, there are: "improved" nano-packaging, which is used to improve the packaging properties: "active" nano-packaging, which allows interaction with food and the environment and plays a dynamic role in food preservation, and "intelligent" or "smart" nano-packaging which is able to monitor the condition of packaged food or the environment surrounding the food (Chaudhry and Castle, 2011; Rhim et al., 2013; Silvestre et al., 2011).

Nanoparticles can be applied as reactive particles incorporated into packaging in a form of nanosensors which provides quality and safety control of products. Nanoparticles used as nanosensors are able to detect the presence of gasses, aromas, chemical contaminants or respond to changes in environmental conditions (Azeredo, 2009; Duncan, 2011).

Excess oxygen is one of the main causes of food deterioration. Use of nanosensors allows easy monitoring of the oxygen content of a package headspace without package destruction, and there are a number of these non-invasive methods. One of these methods is photo activated indicator ink for in-package oxygen detection which is based upon nanosized $\mathrm{TiO}_{2}$ or $\mathrm{SnO}_{2}$ particles and a methylene blue. In response to even minute quantities of oxygen indicator gradually changes colour. The colour of the films varies according to $\mathrm{O}_{2}$ exposure- it is bleached when there is no exposition and blue when film is exposed. Sensors may detect presence of some other gases such as gaseous amines, which are indicators of fish and meat spoilage, in very low concentrations (Azeredo, 2009; Mills and Hazafy, 2009; Duncan, 2011).

Similar to gases sensor, moisture sensor based on nanotechnology is developed. This sensor allows quick and accurate determination of package moisture levels without invasive sampling. Under the influence of humidity polymer, matrix from the packaging swells, which results in larger degrees of inter-nanoparticle separation. These changes cause sensor strips to reflect or absorb different colours of light which can be monitored (Duncan, 2011).

Nanosensors can be used for detection of small organic and inorganic molecules, as well. In this way, the presence of many meats and, in general, food contaminants such as melamine, pesticide, some protein-based bacterial toxins, etc., can be determined (Duncan, 2011).

It is important to be able to monitor all of these parameters and any changes in food product, because the food expiration date is estimated by industries in consideration of distribution and storage conditions ideal or in predicted limits, which is not always the case in practice (Azeredo, 2009; Duncan, 2011).

Considering food safety aspect, the effect of nano-packaging and microbial sensors on food pathogenic and spoilage microorganisms should be discussed. Despite efforts and improvements in slaughter hygiene and food production techniques, food-borne pathogens found in meat, such as Salmonella spp., Campylobacter spp., E. coli, still present a cause of millions episodes of illness annually all over the World (Burt, 2004; Sofos, 2008; Newell et al., 2010; Duncan, 2011; Linscott, 2011; Bošković et. al, 2013).

The incorporation of substances with antimicrobial properties into food packaging materials could help to inhibit growth of pathogenic and spoilage microorganisms. Nanoparticles have a higher surface-to-volume ratio which allows them to attach more copies of biological molecules then their micro scale counterparts (Azeredo, 2009). There are many components which are used as antimicrobial films for food packaging, but the most used is silver because of its activity against Gram-negative and Gram-positive bacteria, fungi, protozoa, and certain viruses (Azeredo, 2009; Velebit and Petrović, 2012; Azeredo, 2013; Lončina et al., 2013). Silver also has high temperature stability and low volatility which are important properties for processing $(\mathrm{Ku}$ mar and Munstedt, 2005; Azeredo, 2009; Azeredo, 2013). The mechanism of the antimicrobial activity of antimicrobial nanocomposite packaging materials based on silver nanoparticles (AgNPs) is still not well explored but it is supposed that packaging gradually releases $\mathrm{Ag}$ ions which result in inhibition of ATP production and DNA replication. Also, it is supposed that Ag ions can directly damage cell membranes by increasing permeability and cause cell death. According to the third described mechanism, antimicrobial activity is a result of generation of reactive oxygen species (ROS) by AgNPs and Ag ions (Dallas et al, 2011; Azeredo, 2013; Rhim et al., 2013). Metal oxide materials, such as titanium dioxide $\left(\mathrm{TiO}_{2}\right)$, zinc oxide $(\mathrm{ZnO})$ and magnesium oxide $(\mathrm{MgO})$, are the most used inorganic nanomaterials. They also exhibit antibacterial activity, which may be attributed to the generation of ROS (Azeredo, 2013). Results from one study in which antibacterial properties of $\mathrm{ZnO}$ nanoparticles were evaluated against Salmonella Typhimurium and Staphylococcus aureus in ready-to-eat poultry meat, have found $\mathrm{ZnO}$ to be highly effective against both bacteria $(A k-$ bar and Anal, 2013). 
Nanomaterial-based microbial sensors present new and promising method to detect presence of pathogens or spoilage microorganisms. Same as convenient biological detection methods, microbial sensors are based on immunological assays (antibodyantigen interactions), but they have different optical and electrical properties which is why their use reduces incubation and measurement times required for accurate detection and improve selectivity. One of these techniques is known as immunomagnetic separation (IMS) which uses magnetic particles attached to selective antibodies in combination with a magnet to selectively separate the target microorganism from the food matrix prior to detection. Using this method E. coli has been isolated from freshly ground beef with more than $94 \%$ capture efficiency and without interference from other tested bacterial species (Duncan, 2011). Use of this or similar methods, as well as antimicrobial nano-packaging, may reduce incidence of food-borne diseases in the future.

\section{Other applications of nanotechnology in meat industry}

Nanotechnology has also been applied in the food manufacture and food processing. For example, nanomaterials have been applied to create nonfouling surfaces in food preparation which prevent clogging of processing machines, reduces the need for cleaning and machine downtime, and lower the cost of production at the same time (Coles and Frewer, 2013).

One of the further perspectives is the use of nanotechnology in meat replacer production. As a matter of fact, fibrillar protein aggregates are developed as meat replacers, and nanotechnology may be one way to enable fibrillar proteins to be constructed to imitate meat (Norde, 2011; Coles and Frewer, 2013).

\section{Impact on human health and other potential risks and issues associated with the use of nanotechnology}

Although nanotechnology offers lot of potential benefits, it may present potential risk for human health, as well as other new and not completely studied innovations.

Nanoparticles can enter the body by dermal contact, inhalation or ingestion (Li and Huang, 2008; Silvestre et al., 2011; Cushen et al., 2012; Rhim et al., 2013). In the food industry, the inhalation and the introduction by dermal contact and trough skin penetration is almost exclusively related to workers in the nanomaterials producing factories which is why use of protective equipment is required (Silvestre et al., 2011), but main exposure of concern for final consumers occurs by ingestion (Cushen et al., 2012). Nanoparticles which are ingested with meat may come directly from meat if they are used as encapsulated additives, from accumulation in plants and animals used in food production or by migration from nanopackaging (Šimon et al., 2008; Cushen et al., 2012; Coles and Frewer, 2013). After entering through the gastro-intestinal tract into circulation the liver and the spleen are the two major organs for distribution (Silvestre et al., 2011).

The effect of nanomaterials on human body/organism depends not only on the method of their introduction, but also on their properties. It has been noted that circulation time increases drastically when the nanoparticles are hydrophilic and their surface is positively charged (Silvestre et al., 2011). Chaudhry and Castle (2011) have suggested that nanomaterials can be classified based on solubility, digestibility, and potential bio persistence. According to them, areas of least concern present food products containing natural food nanostructures, which are either digested or solubilized in the gastrointestinal tract, and which are not bio persistent. In areas of some concern, they classify food products containing encapsulated food additives in nano-sized carriers, which may not be bio persistent, but may carry the encapsulated substances across the gastrointestinal tract, while areas of major concern are food products containing insoluble, indigestible, and potentially bio persistent nano-additives such as metals or metal oxides. Nanoparticles from last category may affect adsorption, distribution, metabolism and elimination, and have potential toxicological effects, which depends mainly on chemical composition and diameter of nanoparticles. Some studies have shown that migration of $\mathrm{Ag}$ ions from packaging is necessary to exhibit antimicrobial effect (Lloret et al., 2012), and exposure to high doses of nanocomposite packaging materials based on silver nanoparticles (AgNPs) is related to liver damage in rats (Azeredo, 2013). Other research has showed that AgNPs are not toxic under strict anaerobic conditions, and that $\mathrm{Ag}$ ions are only released from AgNPs under aerobic conditions demonstrating that the antimicrobial activity of AgNPs is not particle-specific but due only to the release of Ag ions (Xiu et al., 2012). ZnO nanoparticles have a genotoxic potential in human epidermal cells even if bulk $\mathrm{ZnO}$ is non-toxic, which suggests the impact of particles' diameter (Sharma et al., 2009). Studies conducted on carbon nanotubes have suggested that their impact on humans is similar to one caused by asbestos (Poland et al., 2008; Coles and Frewer, 2013). 
Some nanoparticles are capable of crossing the blood brain barrier, and may enter cells and organs and interact with metabolism in ways which are not known and well-studied (Leroueil et al., 2007; Coles and Frewer, 2013) or migrate in the foetus (Silvestre et al., 2011).

Many researches in this field have to be conducted in order either to confirm or to reject the hypothesis that nanoparticles are dangerous to human health and in which way.

Problem associated with human health is also the potential use of nanotechnologies in veterinary medicine in different areas such as production of vaccines with enhanced delivery, some drugs and in animal feed (Morein et al., 2004; Chaudhry and Castle, 2011; Cushen et al., 2012). If the use of nanotechnologies in these purposes becomes established in veterinary medicines, the issue of food, especially meat safety, will be raised. Toxicological information on any possible accumulation of drug/ feed nanocomponents and metabolism of such materials, as well as clearance/withdrawal times would need to be determined to ensure safe levels at time of slaughter (Cushen et al., 2012).

Nanoparticles can have unpredictable impact not only on humans and animals but on the environment, as well (Klaine et al., 2008; Azeredo, 2013; Coles and Frewer, 2013). For example, during waste disposal of $\mathrm{AgNPs}, \mathrm{Ag}$ ions could be released and may accumulate in the environment, where they would continue to kill micro-organisms resulting in disturbed balance in natural micro flora, especially in aquatic system. Also, there is evidence which suggests that exposure to titanium oxide reduces reproductive output in zebrafish, and may damage gills (Fabrega et al., 2011; Coles and Frewer, 2013). Nano-iron, carbon nanotubes, but also some other nanoparticles mainly from nano-pesticide, but from other sources as well, may accumulate in the soil from where they can be absorbed by plants and enter the food chain, indirectly (Azeredo, 2013; Coles and Frewer, 2013).

\section{Legal aspects}

Despite increasingly rapid development of nanotechnology, even though nanotechnology is already present on some markets, at the moment there are no specific regulations on food nanotechnology applications in Europe or in other parts of the World. One of the main reasons is the diversity of these applications but also inability to assess risk from nanotechnology applications. In Europe there is attempt to implement nanotechnology applications in already existing legislation or maybe to modify those for this purpose (European Commission, 2008a; Coles and Frewer, 2013). There are a number of regulations that need to be taken into account, including both so-called horizontal and vertical legislation. The regulations within the scope of horizontal legislation are: Directive 2001/95/EC on general product safety (General Product Safety Directive - GPSD), which covers all goods on the market, goods that could potentially be placed on the market and those supplied or made available to consumers, and it refers to human health; REACH Regulation, (EC) No 1907/2006, under which standard information requirements for substances manufactured in or imported into the EU depend on the weight of chemical manufactured/imported per year and the hazard class, and it refers not only to human health but also on preventing harm to the environment; Regulation (EC) No 1272/2008 refers to the classification, labelling and packaging of substances and mixtures, and Directive Concerning the Placing of Biocidal Products on the Market (98/8/EC). Regulations in European vertical legislation are: Regulation (EC) No 1223/2009, also known as the Cosmetics Regulation; The Regulation on Materials and Articles Intended for Food Contact, (EC) No 1935/2004, regulates food packaging, including new types of materials which actively maintain or improve the condition of the food which is one of the main potential use of nanomaterials; the Food Additive Directive (89/109/EEC); Novel Foods Regulation (EC Regulation 258/97), which propose is approval required to ensure food products made with nanotechnology are safe, and the regulation entitled Active and Intelligent Materials and Articles Intended to Come in Contact with Food, (EC) No 450/2009. Apart from the mentioned, it should be paid attention to Safety and Health of Workers, Directive 89/391/EE, IPPC Directive (EU Council Directive 2008/1/EC), the Seveso II (Directive 96/82/EC), the Water Framework Directive (Directive 2000/60/EC), Waste Framework (Directive 2008/98/EC) and EC Communication on Regulatory Aspects of Nanomaterials (COM (2008) 366 final) (Cushen et al., 2012; Coles and Frewer, 2013).

In spite of a number of federal agencies in the USA, which regulate products associated with nanotechnologies and nanomaterials, as a result of complexities of nanotechnology and leak of knowledge, still there is no regulation scope that provides consistent screening and protection for consumers (Cushen et al., 2012).

In Australia, use of nanotechnologies is also regulated by horizontal legislation, and NICNAS, which regulates chemicals for the protection of human health and the environment, that has recently 
been modified and now determines volumes, types and data holdings of nanomaterials being used ( $L y$ ons and Whelan, 2010; Cushen et al., 2012).

In Taiwan, the Nano Mark System has been introduced, which presents quality- like symbol of assurance to consumers which certifies that a product uses a genuine nanotechnology, and it refers to "nanoingredients" (Chau et al., 2007; Cushen et al., 2012).

Generally, this situation with no appropriate regulation for nanotechnology and its applications put manufacturers in difficult position and also may slow down the developments on this area (Coles and Frewer, 2013).

\section{Public perception and acceptance of nanotechnology}

It's not the product and its wellbeing but public perception and consumers' opinion which play the main role in determining the commercial success on some field. People are generally sceptical about an innovation and new technologies which also applies to nanotechnology, especially its use in the field of food production. Many researchers have showed that knowledge plays an important role in acceptance of new technologies and nanotechnology , but also consumers' perception depends on trust in institutions producing nanotechnology foods and social, economic, and political environments (Currall et al., 2006; Castellini et al., 2007; Siegrist et al., 2007; Siegrist et al., 2008; Kahan et al., 2009; Silvestre et al., 2011). Some studies have examined the public perception of nanotechnology in the USA and in Europe, as well, and have demonstrated that different consumer perceptions towards food nanotechnology in these countries. In both cases results have showed that public knowledge about nanotechnology is very limited. In USA consumers expected many advantages of nanotechnology for safer and better food, and, despite potential risks, they were willing to use specific products containing nanoparticles if benefits are high. In Europe, perceptions were less positive and consumers were sceptical of the use of nanoparticles in food, while they thought that there is a perspective for use of nanotechnology in some other fields which are not associated with food production (Cobb and Macoubrie, 2004; Currall et al., 2006; Castellini et al., 2007; Siegrist et al., 2007.; Kahan et al., 2009; Silvestre et al., 2011). Results of the study conducted by Siegrist et al. (2007) whose objective was to determine perception of nanotechnology utilization suggest that nanotechnology packaging is perceived as being more beneficial and presents a less health risk than nanotechnology foods. It was confirmed in study where consumers have assessed that application of nanoparticles directly in food is most critical way of nanotechnology application because of high levels for negative impact and low levels for control (Siegrist et al., 2007).

Use of nanotechnology in the food industry seems to be close to artificial food additives and genetically modified (GM) products (Coles and Frew$e r, 2013)$, and because people preferred so called natural food, perceived naturalness or lack of it could be a factor that also influences attitudes toward nanotechnology foods (Siegrist et al., 2007).

\section{Conclusion}

Nanotechnology has found its way into the food industry and can be applied in all aspects of the food chain (from farm-to-fork) for improving food safety and quality control, and as novel food supplements, additives or nutrients. Nano-packaging systems are currently the most promising use of nanotechnology in meat and meat products. In spite of all benefits and opportunities which use of nanotechnology offers, there are still some issues related mainly to regulations and legal aspects. Also, there are concerns about impact of nanoparticles on human health and environment, which affect public perception and consumers' acceptance of nanotechnology application in food industry. However, nanotechnology provides lot of opportunities in all sectors, but still researches need to be conducted in order to fulfil current knowledge gaps in this field. 


\section{References}

Akbar A., Anal A.K., 2013. Zinc oxide nanoparticles loaded active packaging, a challenge study against Salmonella typhimurium and Staphylococcus aureus in ready-to-eat poultry meat, Food Control doi: 10.1016/j. foodcont.2013.09.065.

Azeredo M. C. H., 2009. Nanocomposites for food packaging applications, Food Research International 42, 1240-1253.

Azeredo M. C. H., 2013. Antimicrobial nanostructures in food packaging, Trends in Food Science \& Technology, 30, 56-69.

Bošković M., Baltić Ž. M., Ivanović J., Đurić J., Lončina J., Dokmanović M., Marković R., 2013. Use of essential oils in order to prevent food borne illness caused by pathogens in meat, Tehnologija Mesa, 54,1, 14-21.

Burt S., 2004. Essential oils: their antibacterial properties and potential applications in foods-a review, International journal of food microbiology, 94, 223-253.

Castellini O. M., Walejko G. K., Holladay C. E., Theim T. J., Zenner G. M., Crone W. C., 2007. Nanotechnology and the public: effectively communicating nanoscale science and engineering concepts. Journal of Nanopart Research, 9, 183-9.

CDC, 2012. CDC estimates of foodborne illness in the United States. http://www.cdc. gov/foodborneburden/2011-foodborne-estimates.html Accessed: Jan 20th, 2012.

Chau C.-F., Wu S.-H., Yen G. C., 2007. The development of regulations for food nanotechnology. Trends in Food Science \& Technology, 18, 5, 269-280.

Chaudhry Q., Scotter M., Blackburn J., Ross B., Boxall A., Castle L., 2008. Applications and implications of nanotechnologies for the food sector. Food Additives \& Contaminants: Part A: Chemistry, Analysis, Control, Exposure \& Risk Assessment, 25, 3, 241-258.

Chaudhry Q., Castle L., 2011. Food applications of nanotechnologies: An overview of opportunities and challenges for developing countries, Trends in Food Science \& Technology, 22, 595-603.

Chen H., Weiss J., Shahidi F., 2006. Nanotechnology in nutraceuticals and functional foods. Food Technology, 60, 30-36.

Cobb M. D., Macoubrie J., 2004. Public perceptions about nanotechnology: Risks, benefits and trust. Journal of Nanoparticle Research, 6, 395-405.

Coles D., Frewer L. J., 2013. Nanotechnology applied to European food production A review of ethical and regulatory issues, Trends in Food Science \& Technology, http://dx.doi.org/10.1016/j.tifs.2013.08.006 (article in press).

Currall S. C., King E. B., Lane N., Madera J., Turner S., 2006. What drives public acceptance of nanotechnology. Natural Nanotechnoly, 1,153-5.

Cushen M., Kerry J., Morris M., Cruz-Romero M., Cummins E., 2012. Nanotechnologies in the food industry - Recent developments, risks and regulation, Trends in Food Science \& Technology, 24, 30-46.

Dallas P., Sharma V. K., Zboril R., 2011. Silver polymeric nanocomposites as advanced antimicrobial agents: classification, synthetic paths, applications, and perspectives. Advances in Colloid and Interface Science, 166, $1-2,119-135$.
Desmond E., 2006. Reducing salt: A challenge for the meat industry, Meat science, 74, 188-196.

Donsí F., Annunziata M., Sessa M., Ferrari G., 2011. Nanoencapsulation of essential oils to enhance their antimicrobial activity in foods. Food Science and Technology, 44, 1908-1914.

Duncan V. T., 2011. Applications of nanotechnology in food packaging and food safety: Barrier materials, antimicrobials and sensors, Journal of Colloid and Interface Science $363,1-24$.

Fabrega J., Luoma S. N., Tyler C. R., Galloway T. S., Lead J. R., 2011. Silver nanoparticles: behaviour and effects in the aquatic environment. Environment International, 37, 2, 517-531.

Greger M., 2007. The human/animal interface: Emergence and resurgence of zoonotic infectious diseases. Critical Reviews in Microbiology, 33, 243-299.

Hyldgaard M., Mygind T., Meyer R. L., 2012. Essential oils in food preservation: mode of action, synergies, and interactions with food matrix components. Front. Microbio. 3:12. doi: 10.3389/fmicb.2012.00012.

Kahan D. M., Braman D., Slovic P., Gastril S., Cohen G., 2009. Cultural cognition of the risk and benefits of nanotechnology. Natural Nanotechnoly 4, 87-90.

Klaine S. J., Alvarez P. J. J., Batley G. E., Fernandes T. F., Handy R. D., Lyon D. Y., 2008. Nanomaterial's in the environment: behaviour, fate, bioavailability, and effects. Environmental Toxicology and Chemistry, 27, 9, $1825-1851$.

Kumar R., Munstedt H., 2005. Silver ion release from antimicrobial polyamide/silver composites. Biomaterials, 26, 2081-2088.

Leroueil P. R., Hong S., Mecke A., Baker J. R., Orr B. G., Banaszak-Holl M. M., 2007. Nanoparticle interaction with biological membranes: does nanotechnology present a Janus face? Accounts of Chemical Research, 40, $5,335-342$.

Lee K. T., 2010. Quality and safety aspects of meat products as affected by various physical manipulations of packaging materials, Meat Science 86, 138-150.

Li L. H., Huang L., 2008. Pharmacokinetics and bio distribution of nanoparticles. Molecular Pharmacology, 5,496-504.

Linscott A. J., 2011. Food-Borne Illnesses. Clinical Microbiology Newsletter, 33, 41-45.

Lloret E., Picouet P., Fernandez A., 2012. Matrix effects on the antimicrobial capacity of silver based nanocomposite absorbing materials. LWT Food Science and Technology, 49, 2, 333-338.

Lončina J., Ivanović J., Baltić T., Dokmanović M., Đurić J., Bošković M., Baltić Ž. M., 2013. Active system packaging of meat and meat products, Veterinary Journal of Republic of Srpska, 13, 1, 5-16.

Lyons K., Whelan J., 2010. Community engagement to facilitate, legitimize and accelerate the advancement of nanotechnologies in Australia. NanoEthics, 4, 1, 53-66.

Mills A., Hazafy D., 2009. Nanocrystalline SnO2-based, UVB-activated, colourimetric oxygen indicator. Sensor and Actuators B: Chemical, 136, 2,344-349. 
Morein B., Hu K.-F., Abusugra I., 2004. Current status and potential application of ISCOMs in veterinary medicine. Advanced Drug Delivery Reviews, 56, 10, 1367-1382.

Murray S., 2007. Food: the world's biggest industry. www. forbes.com/2007/11/11/growth-agriculture-businessforbeslife-food07-cx_sm_1113bigfood.html

Newell D. G., Koopmans M., Verhoef L., Duizer E., Aidara-Kane A., Sprong H., Opsteegh M., Langelaar M., Threfall J., Scheutz F., van der Giessen J., Kruse H., 2010. Food-borne diseases. The challenges of 20 years ago still persist while new ones continue to emerge, International Journal of Food Microbiology, 139, S3-S15.

Norde W., 2011. Introduction. In L. J. Frewer, W. Norde, A. R. H. Fisher, \& F. W. H. Kampers (Eds.), Nanotechnology in the agrifood sector: Implications for the future. Weinham, Germany:Wiley-VCH.

Ozimek L., Pospiech E., Narine S., 2010. Nanotechnologies in food and meat processing, Acta Sci Pol Technol Aliment, 9, 4, 2010, 401-412.

Poland C., Duffin R., Kinloch I., Maynard A., Wallace W. A. H., Scaton A., Stone V., Brown S., MacNee W., Donaldson K., 2008. Carbon nanotubes introduced into the abdominal cavity of mice show asbestos-like pathogenicity in a pilot study. Nature Nanotechnology, 3, 423-428.

Pronk M. E. J., Wijnhoven, S. W. P., Bleeker E. A. J., Heugens E. H. W., Peijnenburg W. J. G. M., Luttik R., 2009. Nanomaterial's under REACH: Nanosilver as a case study RIVM report 601780003/2009. Bilthoven, the Netherlands: RIVM.

Rhim J. W., Park H. M., Ha C. S., 2013. Bio-nanocomposites for food packaging, applications, Progress in Polymer Science 38, 1629- 1652.
Sharma V., Shukla R. K., Saxena N., Parmar D., Das M., Dhawan A., 2009. DNA damaging potential of zinc oxide nanoparticles in human epidermal cells. Toxicology Letters, 185, 3, 211-218.

Siegrist M., Cousin M. E., Kastenholz H., Wiek A., 2007. Public acceptance of nanotechnology foods and food packaging: The influence of affect and trust. Appetite, 49, 459-466.

Siegrist M., Stampfli N., Kastenholz H., Keller C., 2008. Perceived risks and perceived benefits of different nanotechnology foods and nanotechnology food packaging, Appetite 51, 283-290.

Silvestre C., Duraccio D., Cimmino S., 2011. Food packaging based on polymer nanomaterials, Progress in Polymer Science 36, 1766-1782.

Sofos J. N., 2008. Challenges to meat safety in the 21 st century, Meat Science, 78, 3-13.

Sorrentino A., Gorrasi G, Vittoria V., 2007. Potential perspectives of bio-nanocomposites for food packaging applications, Trends in Food Science \& Technology 18, 84-95.

Šimon P., Chaudhry Q., Bakos D., 2008. Migration of engineered nanoparticles from polymer packaging to foodea physicochemical view. Journal of Food and Nutritional Research, 47, 3, 105-113.

Velebit B., Petrović Z., 2012. Antimicrobial packaging in food industry. Tehnologija Mesa, 53, 71-79.

Weiss J., Gibis M., Schuh V., Salminen H., 2010. Advances in ingredient and processing systems for meat and meat products. Meat Science, 86, 196-213.

Xiu Z., Zhang Q., Puppala H. L., Colvin V. L., Alvarez P. J. J., 2012. Negligible particle-specific antibacterial activity of silver nanoparticles. Nano Letters, 12, 4271-4275.

\title{
Nanotehnologija i njena potencijalna primena u industriji mesa
}

\author{
Baltić Ž. Milan, Bošković Marija, Ivanović Jelena, Dokmanović Marija, Janjić Jelena, Lončina Jasna, \\ Baltić Tatjana
}

$R$ e z i $m$ e: Industrija hrane ulaže velike napore u cilju unapređenja higijene, povećanja održivosti proizvoda, sprečavanja pojave bolesti prenosive hranom, sprečavanja kontaminacije proizvoda hemijskim i fizičkim zagađivačima, kao i poboljšanja njihove detekcije i kontrole, ukoliko je do kontaminacije već došlo. Kao posledica toga, neprekidno se traga za novim tehnologijama koje mogu da pomognu u ostvarenju ovih ciljeva. Jedna od inovacija koja je već našla primenu na mnogim poljima jeste upotreba nanotehnologije. Rezultati dosadašnjih istraživanja pokazuju da upotreba nanotehnologije pruža veliki broj mogućnosti u poboljšanju procesa proizvodnje, pakovanja, distribucije i skladištenja hrane, a samim tim i mesa, koje predstavlja jednu od nutritivno najvrednijih namirnica.

Ključne reči: nanotehnologija, nanopakovanja, meso, problemi i prednosti.

Paper received: 18.11 .2013 .

Paper accepted: 21.11.2013. 